\title{
Implementasi Seiri, Seiton, Seiso, Seiketsu dan Shitsuke di PT. Laksana Kurnia Mandiri Sejati Bandung dan Pengaruhnya Terhadap Efektivitas Organisasi
}

\author{
Yosep Hernawan
}

yosep.hernawan@yahoo.com

\begin{abstract}
Abstrak
Dalam penelitian ini peneliti menggunakan lima variabel yaitu seiri, seiton, seiso, seiketsu dan shitsuke sebagai variabel independent (X) dan efektivitas organisasi sebagai variabel dependent (Y). Penelitian ini dilakukan dengan tujuan untuk mengetahui implementasi dan mengetahui sejauh mana faktor-faktor yang mempengaruhi efektivitas organisasi dengan variabel yaitu seiri, seiton, seiso, seiketsu dan shitsuke di PT. Laksana Kurnia Mandiri Bandung.

Populasi dalam penelitian ini adalah para operator lantai produksi dan maintenance serta supervisor produksi dan supervisor maintenance. Teknik sampel yang digunakan yaitu teknik sampel Slovin, didapatkan jumlah sampel sebanyak 150 dengan penambahan sampai 200. Analisis statistik yang digunakan adalah analisis jalur, Uji T dan Uji F dengan tingkat signifikan $(\alpha) 5 \%$ dan dengan bantuan penggunaan program IBM SPSS 20.

Berdasarkan hasil penelitian dan pembahasan selama periode penelitian, hasil penelitian menunjukan bahwa implementasi seiri, seiton, seiso, seiketsu dan shitsuke belum diterapkan secara optimal walaupun berdasarkan hasil perhitungan statistik seiri, seiton, seiso, seiketsu dan shitsuke mempunyai pengaruh terhadap efektivitas organisasi dengan nilai yang berbeda-beda.
\end{abstract}

Kata Kunci: Seiri (Ringkas), Seiton (Rapi), Seiso (Resik), Seiketsu (Rawat), dan Shitsuke (Rajin), efektivitas organisasi

\begin{abstract}
In this research, researcher used five variables are: seiri, seiton, seiso, seiketsu and shitsuke as an independent variable $(X)$ and efectiveness or oerganization as the dependent variable (Y). This research was conducted with the aim to identify implementation and the effect of them to the effectiveness of the organization in PT. Laksana Kurnia Sejati Mandiri Bandung.

The population is operators from the production floor and maintenance, supervisor of production and supervisor of maintenance. Sampling uses Slovin, number of sample is 200. Statistical analysis used was path analysis, $T$ test and $F$-test with a significant level ( $\alpha$ ) of 5\% and with the help of the program use of IBM SPSS 20.

Based on the result of research and discussion suggest that partially, The result is implementation of seiri, seiton, seiso, seiketsu and shitsuke not optimal yet, although its influences to the effectiveness of the organization.
\end{abstract}

Keywords : Seiri (sort), Seiton (set in order), Seiso (shine), Seiketsu (standardize), and Shitsuke (sustain), organizational effectiveness. 


\section{Pendahuluan}

Persaingan dunia industri saat ini sangat tinggi, masuk ke dalam semua lini perusahaan. Perusahaan di dunia industri dengan tekanan kompetisi yang ketat dituntut untuk selalu melakukan perbaikan di setiap lini produksi, di setiap komponen perusahaan (modal, material, manusia, mesin dan energi) dan harus dilakukan secara berkesinambungan. Untuk menjawab tantangan tersebut setiap perusahaan selayaknya terus berupaya agar proses produksinya dapat berjalan dengan efektif dan efisien sehingga diperlukan pengaturan strategi yang efektif dan efisien juga dari segi tenaga, waktu dan biaya. Terkait dengan hal-hal di atas, maka setiap perusahaan di setiap negara harus memiliki dan menerapkan suatu cara kerja yang mampu mengatur dan mengorganisasi semua kegiatan yang berlangsung di tempat kerja.

Maka setiap organisasi pasti memiliki budaya organisasi yang berbeda-beda. Karena budaya organisasi merupakan nilainilai dominan yang didukung oleh organisasi, falsafah yang menuntun kebijaksanaan organisasi terhadap pegawai dan pelanggan, cara pekerjaan yang dilakukan di tempat itu, dan asumsi kepercayaan dasar yang terdapat diantara anggota organisasi. Budaya organisasi merujuk pada suatu sistem pengertian yang diterima secara terbuka. Semua itu menciptakan pemahaman yang sama diantara para anggota mengenai bagaimana sebenarnya organisasi itu dan bagaimana anggotanya harus berperilaku.

Kuat atau lemahnya budaya organisasi akan mempengaruhi pencapaian organisasi dan efektivitas organisasi tersebut. Budaya organisasi yang kuat dicirikan oleh nilai inti dari organisasi yang dianut dengan kuat, diatur dengan baik, dan dirasakan bersama secara luas. Makin banyak anggota yang menerima nilai-nilai inti, menyetujui jajaran tingkat kepentingannya, dan merasa sangat terikat kepadanya, maka makin kuat budaya organisasi tersebut. Keefektivan organisasi mensyaratkan bahwa budaya, strategi, lingkungan dan teknologi sebuah organisasi bersatu. Makin kuat budaya organisasi, makin penting bahwa budaya tersebut cocok dengan variabel-variabel tersebut.

Sejak dulu berbagai perusahaan manufaktur di Jepang telah menerapkan konsep pengaturan, pemeliharaan dan pengorganisasian di perusahaannya untuk mencapai efektivitas dan efisiensi perusahaan. Contoh lain dari hal tersebut misalnya data mengenai rata-rata setiap pegawai Toyota menghasilkan 57,7 buah mobil setiap tahun. Sebaliknya, Ford hanya memperoleh 16,1 buah mobil dari setiap pegawainya. Demikian juga Toyota hanya mengeluarkan $\$ 630$ untuk upah per mobil, sementara Ford harus mengeluarkan \$2379. Akan tetapi Ford hanya memperoleh $\$ 555$ per mobil dan Toyota mendapatkan $\$ 466$ per mobil. Dilihat dari data di atas jelas sekali bahwa Toyota merupakan perusahaan yang efektif.

Banyak konsep atau nilai-nilai yang sudah diterapkan di tempat kerja perusahaanperusahaan Jepang dan akhirnya dijadikan sebagai pola keyakinan dan nilai-nilai yang dipahami dan dijiwai oleh anggota perusahaan sehingga pola tersebut memberikan makna tersendiri bagi perusahaan tersebut dan dijadikan aturan berperilaku dalam perusahaan yang secara tidak langsung menjadikannya budaya organisasi. Salah satu konsepnya adalah konsep 5S. 5S sendiri adalah salah satu pilar dari tiga pilar utama gemba kaizen. $5 \mathrm{~S}$ merupakan singkatan lima istilah Jepang yaitu Seiri (Ringkas), Seiton (Rapi), Seiso (Resik), Seiketsu (Rawat), dan Shitsuke (Rajin), yang merangkum serangkaian aktivitas untuk menghilangkan pemborosan yang menyebabkan kesalahan, cacat, dan kecelakaan di tempat kerja.

Salah satu perusahaan yang bergerak di bidang tersebut adalah PT. Laksana Kurnia Mandiri Sejati (PT. Lakumas). Saat ini PT. Lakumas terus menerus berusaha membuat 
perbaikan di setiap lini untuk mencapai efektivitas perusahaan. Adapun keefektivan organisasi atau perusahaan ini dapat diukur dengan variabel pencapaian tujuan, pendekatan sistem, konstituensi-strategis, dan nilai-nilai bersaing. Variabel-varabel tersebut dapat direpresentasikan oleh peningkatan laba dengan menekan biaya per unit yang rendah, lead time yang pendek, biaya maintenance yang murah, penanganan atau sirkulasi bahan baku yang baik, keamanan kerja, dan produk berkualitas sesuai keinginan konsumen dan dapat bersaing dengan para pesaing.

Akan tetapi di PT. Laksana Kurnia Mandiri Sejati Bandung hal-hal tersebut masih belum tercapai secara optimal. Efisiensi yang telah ditargetkan oleh perusahaan sebesar $75 \%$ masih sulit untuk dicapai, ratarata pencapaian paling besar hanya sampai $62 \%$. Beberapa klien masih memberikan umpan balik negatif atau komplain kepada perusahaan, baik terkait waktu pengiriman yang terlambat maupun dari kualitas produk. Di samping itu masih banyak terjadi pemborosan (muda, Bahasa Jepang), pemborosan mulai dari mencari jenis bahan baku karena tidak terdapat papan nama bahan baku, pencarian gerigi mesin karena peletakan yang tidak rapi dan tidak sesuai tempatnya, kebersihan dan perawatan alatalat, ruangan dan mesin yang tidak dilakukan setiap saat sehingga menigkatkan waktu aus lebih cepat, keadaan yang tidak resik dan berantakan sehingga berpotensi menyebabkan kecelakaan kerja lebih tinggi. Penanganan dan pengaturan barang-barang seperti peralatan maintenance, komponenkomponen mesin produksi dan laboratorium, peralatan kantor belum mencerminkan falsafah 5S.

Berdasarkan observasi di lapangan diatas terlihat hanya untuk menemukan satu barang saja memerlukan waktu 29 menit, ini merupakan pemborosan dan inefisiensi. Waktu yang tidak produktif, akan berpengaruh pada lamanya proses produksi, delay, dan lead time. Energi pegawai pun akan terbuang percuma, akan dapat mempercepat fatique. Proses produksi tidak optimal dan efesien.

Jika para karyawan mempunyai kebiasaan untuk menyimpan barang sesuai tempatnya, meletakannya secara rapi dan diberi papan nama, membersihkannya sebagai upaya pemeriksaan, merawatnya, dan melakukan semua itu dengan berkesinambungan dan dijadikan sebagai kebiasaan sehingga menjadi perilaku sehari-hari dan menjadikannya sebagai budaya organisasi maka efektivitas organisasi dapat tercapai secara optimal. Misalnya dengan memangkas waktu mencari gerigi mesin spinning, dari 29 menit menjadi 5 menit, karena barang langsung diambil sesuai tempatnya dan ada papan namanya. maka waktu 24 menit adalah waktu yang berharga untuk dipakai sebagai proses produksi, sehingga dapat meningkatkan efisiensi dan menurunkan lead time. Sehingga waktu pengiriman diharapkan tepat waktu dan meminimalisir komplain dari klien. Dengan demikian produk bermutu yang dimulai dari proses yang efisien dapat mudah dicapai dan diharapkan memuaskan konsumen yang pada akhirnya meningkatkan laba perusahaan.

Adapun dengan menjaga kebersihan sebagai salah satu langkah pemeriksaan dapat menurunkan jumlah produk cacat, penataan barang rapi dan sesuai tempatnya dapat mengurangi kecelakaan kerja dan memangkas biaya perawatan dan perbaikan. Dengan mengurangi pemborosan waktu, tenaga, dan biaya maka penekanan biaya produksi per unit untuk meningkatkan efektivitas perusahaan bukan hal yang sulit dilakukan. Maka efektivitas organisasi dapat tercapai melalui upaya kecil berkesinambungan yang dijadikan sebagai budaya organisasi.

Sehubungan dengan hal tersebut, dapat diperkirakan bahwa efektivitas organisasi di PT. Laksana Kurnia Mandiri Bandung dipengaruhi oleh Seiri (Ringkas), Seiton 
(Rapi), Seiso (Resik), Seiketsu (Rawat), dan Shitsuke (Rajin).

\section{Kajian Pustaka}

\subsection{Budaya Organisasi dan Kaizen}

Budaya organisasi (organization culture) sebagai suatu sistem makna bersama yang dianut oleh anggota-anggota yang membedakan organisasi tersebut dengan organisasi lain (Robbins, 2002:63). Sebuah sistem pemaknaan bersama dibentuk oleh warganya yang sekaligus menjadi pembeda dengan organisasi lain. Sistem pemaknaan bersama merupakan seperangkat karakter kunci dari nilai-nilai organisasi (a system of shared meaning held by members that distinguishes the organization form other organization. This system of shared meaning is, on closer examination, a set of key characteristics that the organization values) (Robbins, 2002:65).

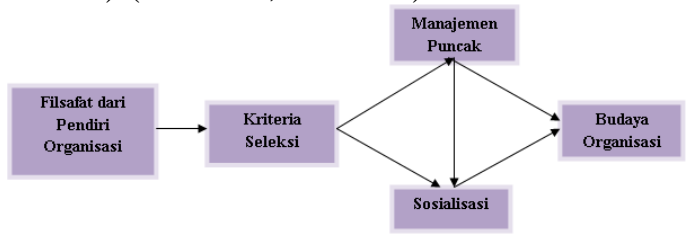

Gambar 2.1. Terbentuknya Budaya Organisasi

Sumber : Teori Organisasi (Robbins, 2002)

Sedangkan fungsi budaya organisasi adalah sebagai berikut:

1. Budaya menciptakan pembedaan yang jelas antara satu organisasi dan yang lain.

2. Budaya membawa suatu rasa identitas bagi anggota-anggota organisasi.

3. Budaya mempermudah timbulnya komitmen pada sesuatu yang lebih luas daripada kepentingan diri individual seseorang.

4. Budaya merupakan perekat sosial yang membantu mempersatukan organisasi itu dengan memberikan standarstandar yang tepat untuk dilakukan oleh karyawan.

5. Budaya sebagai mekanisme pembuat makna dan kendali yang memandu dan membentuk sikap serta perilaku karyawan (Robbins, 1996 : 294).

Terdapat 7 ciri-ciri budaya organisasi adalah sebagai berikut:

1. Inovasi dan pengambilan resiko, sejauh mana karyawan didukung untuk menjadi inovatif dan mengambil resiko.

2. Perhatian terhadap detail, sejauh mana karyawan diharapkan menunjukkan kecermatan, analisis dan perhatian terhadap detail.

3. Orientasi hasil, sejauh mana manajemen memfokus pada hasil bukannya pada teknik dan proses yang digunakan untuk mencapai hasil tersebut.

4. Orientasi orang, sejauh mana keputusan manajemen memperhitungkan efek pada orangorang di dalam organisasi itu.

5. Orientasi tim, sejauh mana kegiatan kerja diorganisasikan sekitar tim-tim, ukannya individu.

6. Keagresifan, berkaitan dengan agresivitas karyawan.

7. Kemantapan, organisasi menekankan dipertahankannya budaya organisasi yang sudah baik.

Adapun kaizen berasal dari Bahasa Jepang yang berarti perbaikan berkesinambungan (Imai, 1999). Secara etimologis kaizen berasal dari kata Kai (han) artinya lebih baik dan Zen (zan) yang artinya perbaikan positif. Kaizen adalah perbaikan berkelanjutan (Continuous Improvement) yang bertumpu pada SDM.

Manajemen harus belajar untuk menerapkan konsep dan sistem yang mendasar tertentu dalam rangka mewujudkan strategi kaizen (Imai, 1999). Dalam konteks kaizen, manajemen memiliki dua fungsi utama: pemeliharaan 
dan perbaikan. Pemeliharaan berkaitan dengan kegiatan untuk memelihara teknologi, sistem manajerial, standar operasional yang ada, dan menjaga standar tersebut melalui pelatigan serta disiplin. Perbaikan, pada sisi lain, berkaitan dengan kegiatan yang diarahkan pada peningkatan standar yang ada. Pandangan manajemen Jepang terhadap manajemen dalam hal ini dapat disimpulkan secara singkat sebagai pemeliharaan dan perbaikan ptandar atau penyempurnaan.

Salah satu konsepnya adalah konsep 5S. 5S sendiri adalah salah satu pilar dari tiga pilar utama gemba kaizen. 5S merupakan singkatan lima istilah Jepang yaitu Seiri (Ringkas), Seiton (Rapi), Seiso (Resik), Seiketsu (Rawat), dan Shitsuke (Rajin), yang merangkum serangkaian aktivitas untuk menghilangkan pemborosan yang menyebabkan kesalahan, cacat, dan kecelakaan di tempat kerja. Konsep 5S merupakan salah satu cara yang dapat diterapkan untuk mencapai suatu Total Quality Environment pada suatu lingkungan kerja, baik itu lingkungan kerja pabrik maupun kantor.

整理 (seiri), Ringkas, merupakan kegiatan menyingkirkan barang-barang yang tidak diperlukan sehingga segala barang yang ada di lokasi kerja hanya barang yang benarbenar dibutuhkan dalam aktivitas kerja. 整頓 (seiton), Rapi， segala sesuatu harus diletakkan sesuai posisi yang ditetapkan sehingga siap digunakan pada saat diperlukan. 清楚 (seiso), Resik, merupakan kegiatan mempersihkan peralatan dan daerah kerja sehingga segala peralatan kerja tetap terjaga dalam kondisi yang baik. 清潔 (seiketsu), Rawat, merupakan kegiatan menjaga kebersihan pribadi sekaligus mematuhi ketiga tahap sebelumnya. 躾け (shitsuke), Rajin, yaitu pemeliharaan kedisiplinan pribadi masing-masing pekerja dalam menjalankan seluruh tahap 5S.
Keunggulan 5S, antara lain:

1. Manajemen Berkesinambungan Menciptakan Tempat Kerja Terbaik: Dua Pola Penyempurnaan (Peluru Perak dan Ancangan Secara Gradual atau Persiapan Rutin dan Berkala)

2. 5S Merupakan Barometer Manajemen: Pabrik yang Berjalan Lancar dikendalikan Oleh Setiap Orang

3. Pabrik Sebagai Alat Penjualan

4. 5S Sebagai Ilmu Perilaku

5. Menggunakan Pengalaman di Pabrik Untuk Membersihkan Batin

6. Sistem yang Menggugah Perilkau Bertanggung Jawab

7. 5S Sebagai Falsafah Manajemen

8. 5S Sebagai Sarana Utama Produktivitas

Untuk memulainya, ada langkah-langkah yang harus diperhatikan (Osada, 2002), sebagai berikut :

1. Memulai tindakan.

2. Penemuan hal baru dan keadaan yang dapat mengubah persepsi.

3. Mengubah tempat kerja dan fasilitas.

4. Mengubah manusia

\subsection{Perilaku Karyawan}

Perilaku organisasional adalah bidang studi yang menyelidiki pengaruh yang ditimbulkan oleh individu, kelompok dan struktur terhadap perilaku manusia di dalam organisasi dengan tujuan menerapkan pengetahuan yang didapat untuk meningkatkan efektifitas organisasi (Robbins, 1986).

Memahami perilaku individu akan membantu dalam memahami perilaku organisasi karena pada dasarnya manusia itu homo homini socius. Manusia tidak bisa lepas dari organisasi, manusia merupakan komponen vital dalam keberadaan dan dinamika sebuah organisasi. Memahami perilaku manusia membutuhkan kerjasama berbagai disiplin keilmuan. 
Empat asumsi penting tentang perilaku Individu:

1. Perilaku timbul karena ada stimulus atau penyebab.

2. Perilaku diarahkan kepada tujuan.

3. Perilaku yang terarah pada tujuan dapat terganggu oleh frustasi, konflik, dan kecemasan.

4. Perilaku timbul karena adanya motivasi (Gibson, 1989).

Pembelajaran adalah perubahan tingkah laku yang relatif menetap yang terjadi sebagai akibat dari pengalaman meliputi perubahan, relatif menetap. Pembentukan perilaku dapat terjadi oleh beberapa hal, diantaranya:

1. Melalui pembelajaran, manajer dapat membentuk perilaku karyawan agar mau melakukan perilaku-perilaku yang menguntungkan perusahaan.

2. Shaping Behavior.

3. Penguatan secara sistematis dan bertahap agar individu dapat berperilaku sesuai harapan.

Sedangkan metode pembentukan karakter dibedakan menjadi:

1. Positive reinforcement, memberikan penghargaan untuk mempertahankan tingkah laku yang diinginkan.

2. Negative reinforcement, dihentikannya perilaku yang tidak menyenangkan untuk menghindari akibat yang tidak diinginkan namun biasanya diikuti tingkah laku baru yang diinginkan.

3. Punishment menerapkan suatu kondisi yang tidak menyenangka atau hukuman untuk menghilangkan perilaku yang tidak diinginkan.

4. Extinction, menyingkirkan penguatan apa saja yang mempertahankan perilaku.

Perilaku organisasional adalah bidang studi yang menyelidiki pengaruh yang ditimbulkan oleh individu, kelompok dan struktur terhadap perilaku manusia di dalam organisasi dengan tujuan menerapkan pengetahuan yang didapat untuk meningkatkan efektifitas organisasi (Robbins, 1986).

\subsection{Efektivitas Organisasi}

Organisasi adalah kumpulan dari individu dan kelompok sehingga keefektifan organisasi pada dasarnya adalah merupakan fungsi dari keefektifan individu dan kelompok (Subkhi dkk, 2013:246). Secara sederhana, organisasi adalah kesatuan susunan yang terdiri dari sekelompok orang yang mempunyai tujuan yang sama, yang dapat dicapai secara bersama, dimana dalam melakukan tindakan itu ada pembagian tugas, wewenang dan tanggung jawab bagi tiap-tiap personal yang terlibat di dalamnya untuk mencapai tujuan organisasi (Subkhi dkk, 2013:246).

Efektivitas adalah hubungan antara output dan tujuan. Ini berarti bahwa seberapa jauh tingkat output, kebijakan dan prosedur dari organisasi mencapai tujuan yang ditetapkan (Subkhi dkk, 2013:246). Dalam Kamus Besar Bahasa Indonesia, efektivitas diartikan sebagai sesuatu yang ada efeknya (akibatnya, pengaruhnya), dapat membawa hasil, berhasil guna (tindakan) serta dapat pula berarti mulai berlaku (tentang undangundang/peraturan).

Keserasian budaya dan efektifitas (keefektifan) organisasi dapat didekati berdasarkan nilai-nilai bersaing dari nilainilai inti organisasinya sesuai level dan peran organisasi dalam pencapaian tujuan jangka pendek dan jangka panjangnya. Nilai-nilai bersaing adalah penekanan organisasi pada dimensi utama sesuai dengan preferensi dari konstituen yang dirasakan atau dikehendaki dan diyakini mempengaruhi efektifitas/keefektifan dan kinerja organisasi

Efektifitas atau keefektifan organisasi dapat didefinisikan sebagai tingkatan pencapaian organisasi atas tujuan jangka pendek dan jangka panjang yang didekati berdasarkan 
nilai-nilai bersaing dari nilai-nilai inti organisasinya. Istilah efektif (effective) menunujukkan seberapa baik proses atau ukuran dalam memenuhi pencapaian tujuan organisasi. Kata efektif berasal dan bahasa inggris effective artinya berhasil, sesuatu yang dilakukan berhasil dengan baik (Moh. Pabundu Tika, 2006: 129). Efektifitas sebagai tingkat pencapaian organisasi jangka pendek dan jangka panjang (Robbins, 1994). Dalam buku "Organizational Psychology" mengemukakan bahwa efektifitas organisasi adalah kemampuan untuk bertahan, menyesuaikan diri, memelihara diri dan tumbuh, lepas dan fungsi tertentu yang dimilikinya (Schein, 1980). Menurut Petters dan Waterman (Robbin, 1994) karakteristik umum dan perusahaanperusahaan efektif terdiri dari:

1. Mempunyai bias terhadap tindakan dan penyelesaian pekerjaan.

2. Selalu dekat dengan para pelanggan agar dapat mengerti secara penuh kebutuhan pelanggan.

3. Memberi para pegawai tingkat otonomi yang tinggi dan memupuk semangat kewirausahaan.

4. Berusaha meningkatkan produktivitas lewat partisipasi para pegawainya.

5. Para pegawainya mengetahui apa yang diinginkan perusahaan dan para manajemya terlibat aktif pada masalah di semua tingkatan.

6. Selalu dekat dengan usaha yang ketahui dan pahami.

7. Mempunyai struktur organisasi yang luwes dan sederhana, dengan jumlah orang yang minimal dalam aktivitasaktivitas staf pendukung.

8. Menggabungkan kontrol yang ketat dan desentralisasi untuk mengamankan nilai-nilai inti perusahaan dengan kontrol yang longgar di bagian-bagian lain untuk mendorong pengambilan risiko serta inovasi.
Kriteria efektifitas organisasi terdiri dan lima unsur, yaitu produksi, efisiensi, kepuasan, keadaptasian. dan kelangsungan hidup (Gibson et al., 1987).

1. Produksi, sebagai kriteria efektifitas mengacu pada ukuran keluaran utama organisasi. Ukuran produksi mencakup keuntungan, penjualan, pangsa pasar, dokumen yang diproses, rekanan yang dilayani, dan sebagainya. Ukuran ini berhubungan secara langsung dengan yang dikonsumsi oleh pelanggan dan rekanan organisasi yang bersangkutan.

2. Efisiensi sebagai kriteria efektifitas mengacu pada ukuran penggunaan sumber daya yang langka oleh organisasi. Efisiensi adalah perbandingan antara keluaran dan masukan. Ukuran efisiensi terdiri dan keuntungan dan modal, biaya per unit, pemborosan, waktu terluang, biaya per orang, dan sebagainya. Efisiensi diukur berdasarkan rasio antara keuntungan dengan biaya atau waktu yang digunakan.

3. Kepuasan sebagai kriteria efektifitas mengacu kepada keberhasilan organisasi dalam memenuhi kebutuhan karyawan atau anggotanya. Ukuran kepuasan meliputi sikap karyawan, penggantian karyawan, absensi, kelambanan, keluhan, kesejahteraan, dan sebagainya.

4. Keadaptasian sebagai kriteria efektifitas mengacu kepada tanggapan organisasi terhadap perubahan eksternal dan internal. Perubahanperubahan ekstemal seperti persaingan, keinginan pelanggan, kualitas produk, dan sebagainya, serta perubahan internal seperti ketidakefisienan, ketidakpuasan, dan sebagainya merupakan adaptasi terhadap lingkungan.

5. Kelangsungan hidup sebagai kriteria efektifitas mengacu kepada tanggung jawab organisasi/perusahaan dalam memperbesar kapasitas dan potensinya untuk berkembang. 
Pemahaman para manajer mengenai efektivitas organisasi sangat mempengaruhi kemampuannya guna memanfaatkan sumber daya yang dimiliki untuk mencapai hasil (value creation). Semakin produktif dan efisien suatu organisasi untuk memanfaatkan sumber daya yang dimilikinya, semakin tinggi value cration yang dicapai. Stoner menekankan pentingnya efektivitas organisasi dalam pencapaian tujuan-tujuan organisasi dan efektivitas adalah kunci dari kesuksesan suatu organisasi. Efektif berbeda dengan efisien. Efektif merupakan achievement of goals sedangkan efisien adalah "the ratio of effective output the input required to achieve it" (Subkhi dkk, 2013:246).

\section{Metode}

Dalam pelaksanaannya, peneliti menganalisis mengenai implementasi dan pengaruh seiri (ringkas), seiton (rapi), seiso (resik), seiketsu (rawat), dan shitsuke (rajin). Analisis yang digunakan adalah analisis jaluer, pengujian asumsi klasik dan pengujian hipotesis melalui uji $\mathrm{t}$ dan $\mathrm{F}$. Metode yang digunakan adalah metode analisis dekriptif dan verifikatif dengan pendekatan kualitatif dan kuantitaif.

Data yang digunakan dalam penelitian ini adalah data primer, yaitu data yang diperoleh secara langsung dari sumber asli (tidak melalui media perantara (Sugiyono, 2013:187). Teknik yang dipergunakan untuk pengumpulan data primer dilakukan dengan observasi, wawancara dan kuesioner kepada responden dengan memberikan panduan dan tata cara pengisian kuesioner.

Dalam penelitan ini yang menjadi populasi dalam penelitian ini adalah para operator lantai produksi dan maintenance serta supervisor produksi dan supervisor maintenance. Teknik sampel yang digunakan yaitu teknik sampel Slovin, didapatkan jumlah sampel sebanyak 150 dengan penambahan sampai 200. Analisis statistik yang digunakan adalah analisis jalur, Uji $\mathrm{T}$ dan Uji $\mathrm{F}$ dengan tingkat signifikan $(\alpha) 5 \%$.

\section{Hasil dan Pembahasan Deskriptif}

Berdasarkan total kumulatif yang didapatkan, maka dapat diketahui perhitungan keadaan responden mengenai seiri, seiton, seiso, seiketsu, dan shitsuke dan efektivitaas organisasi.

Tabel 4.1. Kriteria Penilaian

\begin{tabular}{c|c}
\hline Kelompok & Kriteria \\
\hline $821-876$ & Sangat Baik \\
\hline $765-820$ & Baik \\
\hline $709-764$ & Cukup Baik \\
\hline $653-708$ & Kurang Baik \\
\hline $597-652$ & Tidak Baik \\
\hline
\end{tabular}

Tabel 4.2 Tanggapan Responden Terhadap Kuesioner Seiri, Seiton, Seiso, Seiketsu, dan Shitsuke terhadap Efektivitas Organisasi

\begin{tabular}{c|c|c}
\hline Variabel & Skor & Kriteria \\
\hline Seiri & 816.4 & Baik \\
\hline Seiton & 725.2 & Cukup Baik \\
\hline Seiso & 700.2 & Kurang Baik \\
\hline Seiketsu & 756.4 & Cukup Baik \\
\hline Shitsuke & 756.2 & Cukup Baik \\
\hline Efektivitas organisasi & 660.25 & Kurang Baik \\
\hline
\end{tabular}

Pada variabel seiri terlihat tanggapan 'baik', semua hal mengenai pemilahan barang sudah terbiasa dilakukan karena sudah ada pada SOP perusahaan. Hal ini erat kaitannya dengan teori bahwa budaya organisasi (organization culture) sebagai suatu sistem makna bersama yang dianut oleh anggota-anggota yang membedakan organisasi tersebut dengan organisasi lain (Robbins, 2002:63).

Untuk variabel seiton, ditanggapi oleh responden dengan nilai 'cukup', sesuai dengan keadaan di pabrik khususnya di bagian produksi dan maintenance masih belum terlihat rapi tetapi tidak terlalu berantakan. Karena belum terbiasa menata barang yang terpakai dan tidak terpakai maka berimbas pada penataan barang yang belum optimal juga. Hal ini karena belum ada SOP dan karywan belum terbiasa, 
kaitannya dengan teori bahwa perilaku timbul karena ada stimulus atau penyebab, perilaku diarahkan kepada tujuan, perilaku yang terarah pada tujuan dapat terganggu oleh frustasi, konflik, dan kecemasan, perilaku timbul karena adanya motivasi (Gibson, 1989).

Pada variabel seiso, memiliki nilai 'kurang baik'. Sebenarnya, kegiatan membersihkan sudah biasa dilakukan oleh setiap karyawan, alat kebersihan pun sudah disediakan oleh perusahaan dan semuanya sudah ada pada SOP perusahaan. Akan tetapi karena kesadaran para karyawan yang masih kurang dan peran perusahaan yang belum optimal untuk membentuk kedisiplinan dan kesadaran para karyawan tersebut terkait kebersihan dengan. Hal ini sangat erat kaitannya dengan budaya organisasi dan pembentukan budaya individu.

Tanggapan responden pada variabel seiketsu masih menempati nilai 'cukup baik'. Mempunyai penyebab yang sama yaitu kesadaran para karyawan yang masih kurang dan peran perusahaan yang belum optimal untuk membentuk kedisiplinan dan kesadaran para karyawan tersebut terkait kebersihan dengan perhatian yang khusus. Hal ini sangat erat kaitannya dengan budaya organisasi dan pembentukan budaya individu.

Untuk variabel shitsuke, memiliki nilai 'cukup baik', para karyawan melakukan hal tersebut sebagai suatu kebiasaan karena ada pada SOP perusahaan. . Hal ini sangat erat kaitannya dengan budaya organisasi dan pembentukan budaya individu.

Pada variabel efektivitas organisasi memilki nilai 'kurang baik'. Hal ini bisa terjadi karena komunikasi antara perusahaan dengan karyawan belum terjalin optimal. Output yang dihasilkan oleh para karyawan belum sesuai dengan tujuan perusahaan. Keserasian budaya dan efektifitas atau keefektifan organisasi dapat didekati berdasarkan nilai-nilai bersaing dari nilai-nilai inti organisasinya sesuai level dan peran organisasi dalam pencapaian tujuan jangka pendek dan jangka panjangnya.

\section{$5 \quad$ Hasil dan Pengujian Hipotesis}

5.1. Analisis Jalur

Analisis jalur dikembangkan oleh Sewall Wright (1934), bertujuan untuk menerangkan akibat langsung dan tidak langsung dari seperangkat variabel bebas terhadap variabel tergantung dan mengetahui hubungan strukturalnya serta dapat menjelaskan besarnya pengaruh langsung dan pengaruh tidak langsungnya, dan pengaruh variabel lain.

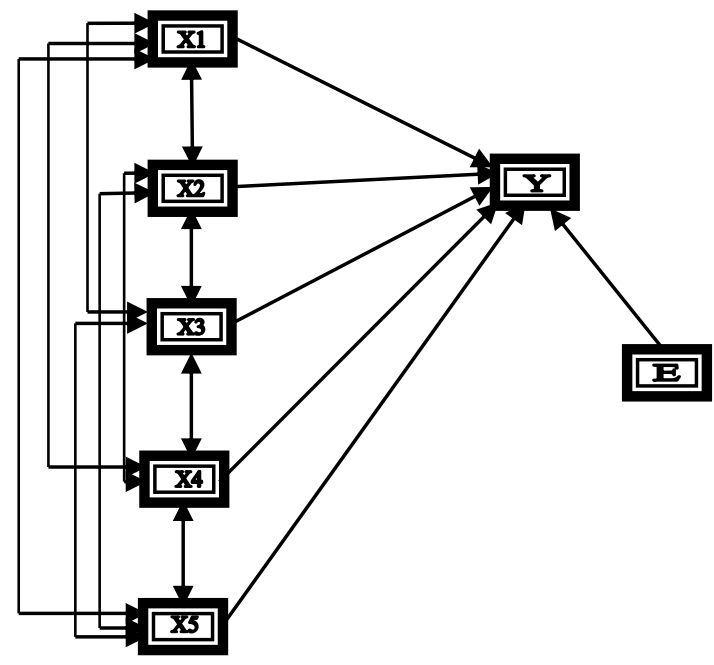

Gambar 5.1.Model Analisis Jalur

Dengan demikian maka dapat dibentuk persamaan sebagai berikut:

$\mathrm{Y}=\boldsymbol{\beta}_{0+} \quad \mathbf{0 , 3 5 1 X 1 +} \quad \mathbf{0 , 0 5 4 X 2 -} \quad \mathbf{0 , 1 1 0 X 3 +}$ $0,217 \times 4+0,466 \times 5+\varepsilon$

\subsection{Uji Statistik}

1) Uji F (Simultan)

Hipotesisnya sebagai berikut:

$\mathrm{H} 0=$ Tidak ada hubungan linear antara Seiri, Seiton, Seiso, Seiketsu, Shitsuketerhadap efektivitas organisasi.

H1= Ada hubungan linear antara Seiri, Seiton, Seiso, Seiketsu, Shitsuketerhadap efektivitas organisasi. 
Pada penelitian ini membandingkan besarnya angka taraf signifikan (sig) penelitian dengan taraf signifikan sebesar 0,05 . Dengan kriteria jika sig. penelitian < 0,05 maka $\mathrm{H} 0$ ditolak dan $\mathrm{H} 1$ diterima dan iika sig. penelitian > 0,05 maka $\mathrm{H} 0$ diterima dan $\mathrm{H} 1$ ditolak. Berdasarkan perhitungan angka signifikasi sebesar $0,00<0,05$ maka H0 ditolak dan H1 diterima, artinya ada hubungan linear antara Seiri, Seiton, Seiso, Seiketsu, Shitsuke terhadap efektivitas organisasi.

\section{2) Uji T}

Kriteria hipotesis:

$\mathrm{H} 0=$ Tidak ada hubungan linear antara seiri dengan efektivitas organisasi

$\mathrm{H} 1=$ Ada hubungan linear antara seiri dengan efektivitas organisasi

Angka t tabel didapatkan sebesar 1,97202.

Uji hipotesisnya adalah jika $\mathrm{t}$ penelitian $>\mathrm{t}$ tabel maka $\mathrm{HO}$ ditolak dan $\mathrm{H} 1$ diterima dan jika t penelitian < t tabel maka $\mathrm{H} 0$ diterima dan H1 ditolak.

a. Pengaruh variabel seiri terhadap efektifitas organisasi sebesar 0,351 atau $35,1 \%$. Titik beratnya adalah manajemen stratifikasi dan mencari faktor-faktor penyebab sebelum hal-hal yang tidak diperlukan tersebut menjadi sebuah masalah. Dengan terbiasanya para karyawan menerapkan seiri maka kriteria efektivitas organisasi dapat terpenuhi antara lain produksi sebagai kriteria efektifitas mengacu pada ukuran keluaran utama organisasi (dalam hal ini dokumen yang diproses), dan efisiensi sebagai kriteria efektifitas mengacu pada ukuran penggunaan sumber daya yang langka oleh organisasi (pemborosan, waktu terbuang) (Gibson et al., 1987).

b. Pengaruh variabel seiton terhadap efektifitas organisasi sebesar 0,054 atau $5,4 \%$. Titik beratnya adalah pada manajemen fungsional dan mengeliminasi aktivitas mencari. Pengaruhnya hanya sebesar 5,4\% masih dikatakan rendah. Padahal idealnya seiton dapat memberikan dampak baik pada efektivitas produksi dan efisiensi seperti halnya seiri. Adapun hal yang membuat pengaruhnya seiton tidak cukup besar di PT. Lakumas Bandung disebabkan pada penataan barangbarang yang belum optimal, seperti yang sudah ditampilkan pada tabel 1.1 Analisis Waktu Pengambilan Gerigi Mc. Spinning.

c. Pengaruh variabel seiso terhadap efektifitas organisasi sebesar $-0,110$ atau $0 \%$. Titik beratnya adalah membersihkan sebagai pemeriksaan dan menciptakan tempat kerja yang sempurna. Dengan hasil perhitungan menunjukan angka $0 \%$, sebenarnya bertentangan dengan teori awal. Asumsi dari hal tersebut adalah bahwa seiso belum menjadi kebiasaan bagi para karyawan dan belum dijadikan sebagai suatu pondasi yang disampaikan perusahaan kepada perusahaannya. Kaitannya adalah bahwa budaya perusahaan dapat digambarkan sebagai kumpulan dari nilai, norma, ungkapan, dan perilaku yang ikut menentukan bagimana orang-orang dalam perusahaan saling berhubungan (Muijen, 1997:23). Memahami perilaku individu akan membantu dalam memahami perilaku organisasi karena pada dasarnya manusia itu homo homini socius.

d. Pengaruh variabel seiketsu terhadap efektifitas organisasi sebesar 0,217 atau $21,7 \%$. Titik beratnya adalah manajemen visual dan standarisasi dan pemantapan 5S. Inovasi dan manajemen visual dilakukan untuk mencapai dan memelihara kondisi terstandarisasi sehingga tindakan dapat diambil dengan cepat. Pembelajaran adalah perubahan tingkah laku yang relatif menetap yang terjadi sebagai akibat dari pengalaman meliputi perubahan, relatif menetap. Pangaruh seiketsu cukup besar, karena pada tingkat organisasi, budaya merupakan serangkaian asumsi, keyakinan, dan nilai-nilai dan persepsi dari anggota organisasi yang mempengaruhi dan membentuk sikap 
dan perilaku kelompok yang bersangkutan (Hofstede, 1994:98).

e. Pengaruh variabel shitsuke terhadap efektifitas organisasi sebesar 0,466 atau $46,6 \%$. Titik beratnya adalah melakukan pekerjaan sebagaimana seharusnya dilakukan. Titik beratnya adalah lingkungan kerja dengan kebiasaan dan disiplin yang baik. Dengan angka 46.6\% adalah nilai yang besar membuktikan bahwa kemantapan, organisasi menekankan dipertahankannya budaya organisasi yang sudah baik menjadi salah satu ciri budaya organisasi. Gambaran ini menjadi dasar untuk perasaan pemahaman bersama yang dimiliki para anggota mengenai organisasi itu, bagaimana urusan diselesaikan di dalamnya, dan cara para anggota berperilaku (Robbins, 1996 : 289).

3) Korelasi antara variabel pada $5 \mathrm{~S}$ Seiri, Seiton, Seiso, Seiketsu, Shitsuke

a. Korelasi Antara Seiri dan Seiton sebesar 0,609. Seiri berarti membedakan atau memisahkan antara yang diperlukan dan yang tidak diperlukan, mengambil keputusan yang tegas, dan menerapkan manajemen stratifikasi untuk membuang hal-hal yang tidak diperlukan. Selanjutnya menyimpan barang yang diperlukan secara rapi atau dalam tata letak yang benar sehingga dapat dipergunakan dalam keadaan mendadak.

b. Korelasi Antara Seiri dan Seiso sebesar 0,473 . Membedakan atau memisahkan antara yang diperlukan dan yang tidak diperlukan dapat memberikan kemudahan dalam menjaga kebersihan.

c. Korelasi Antara Seiri dan Seiketsu sebesar 0,856. Dengan pemisahan antara yang diperlukan dan yang tidak diperlukan maka perawtan barang akan mudah dikerjakan.

d. Korelasi Antara Seiri dan Shitsuke sebesar 0,762. membedakan atau memisahkan antara yang diperlukan dan yang tidak diperlukan, mengambil keputusan yang tegas, dan menerapkan manajemen stratifikasi memerlukan sikap yang rajin dan berkesinambungan.

e. Korelasi Antara Seiton dan Seiso sebesar 0,467 . Pada kerapian selalu ada kebersihan, jika barang yang sudah tertata dengan rapi maka kotorankotoran akan mudah terlihat.

f. Korelasi Antara Seiton dan Seiketsu sebesar 0,814. Kerapian yang sudah terlaksana akan memberikan kemudahan dalam perawatan, dan akan memangkas biaya-biaya pemeliharaan.

g. Korelasi Antara Seiton dan Shitsuke sebesar 0,888 . Tata letak yang baik memberikan gambaran dan sikap rajin dan terus menerus terpelihara, karena keadaan yang rapi tidak akan mentolerir ketidakrapian.

h. Korelasi Antara Seiso dan Seiketsu sebesar 0,430. Kebersihan akan memberikan keuntungan dalam meringankan biaya perawatan dan beban pemeliharaan.

i. Korelasi Antara Seiso dan Shitsuke sebesar 0,550. Kebersihan memberikan sikap rajin dan keadaan nyaman dalam bekerja.

j. Korelasi Antara Seiketsu dan Shitsuke sebesar 0,814. Perawatan merupakan awal dari sikap rajin yang harus dipelihara dan terus dilakukan secara berkesinambungan.

\section{Kesimpulan dan Saran}

\subsection{Kesimpulan}

Dari hasil penelitian dan analisis yang telah dilakukan pada bab sebelumnya, maka penelitian ini dapat menghasilkan kesimpulan sebagai berikut:

1) PT. Laksana Kurnia Mandiri secara sadar ataupun tidak telah menerapkan program 5S walaupun belum dapat dikatakan sempurna. Hal ini dapat terlihat dari tanggapan para karyawan sebagai responden ketika diberikan kuesioner, setelah dianalisis jawabanjawaban kuesioner tersebut ada beberapa program dari $5 \mathrm{~S}$ yang masih belum diterapkan atau dilaksanakan oleh para karyawan. Hal ini bisa dipengaruhi oleh 
berbagai hal, diantaranya kebijakan pemilik perusahaan, budaya kerja yang sulit diubah, tingkat kesadaran para karyawan sendiri, tingkat pendidikan, lamanya bekerja atau pengalaman kerja, pengawasan dan sosialisasi berkelanjutan dari pihak manajemen.

2) Hasil penelitian ini menunjukan bahwa ada hubungan antara penerapan Seiri, Seiton, Seiso, Seiketsu, Shitsuke terhadap efektivits organisasai dengan nilai yang berbeda-beda. Shitsuke sebagai variabel independen yang mempunyai pengaruh terbesar terhadap efektivitas organisasi di PT. Laksana Kurnia Mandiri sebesar 46,6\%. Hal ini menunjukan bahwa program Shitsuke di PT. Laksana Kurnia Mandiri banyak mempengaruhi efektivitas organisasi perusahaan dalam hal ini titik beratnya adalah melakukan pekerjaan sebagaimana seharusnya dilakukan. Titik beratnya adalah lingkungan kerja dengan kebiasaan dan disiplin yang baik. Penanganan disiplin untuk membentuk sikap rajin di PT. Lakumas sudah baik, akan tetapi penanaman budaya organisasi $5 \mathrm{~S}$ secara keseluruhan belum optimal ini terlihat dari nilai seiso yang rendah yaitu $0 \%$. Hal ini mencerminkan bahwa keadaan kebersihan sebagai salah satu definisi seiso tidak terlalu menjadi fokus utama kebijakan di PT. Laksana Kurnia Mandiri dalam mempengaruhi efektivitas organisasi.

\subsection{Saran}

Berdasarkan hasil penelitian dan melihat kondisi yang berjalan saat ini, maka ada beberapa saran yang perlu dipertimbangkan:

1) Penerapan $5 \mathrm{~S}$ perlu dilakukan secara menyeluruh dan berkelanjutan, akan lebih baik ada penelitian lanjutan yang menitikberatkan pada langkah-langkah praktis mengenai sosialisasi dan penerapan program 5S di semua sektor bisnis maupun nirlaba.
2) Sebagai catatan, seiso mempunyai nilai yang paling rendah, maka sangat penting untuk mengetahui dengan tepat tempat melakukan pemeriksaan, terutama pada mesin-mesin dan fasilitas yang harus bebas kotoran. melakukan pembersihan sehingga segala sesuatunya bersih. Pada terminologi 5S, Seiso berarti menyingkirkan sampah, kotoran, dan lain-lain sehingga segala sesuatunya bersih. berusaha mencapai kotoran nihil dan debu nihil serta menghilangkan cacat dan kesalahan kecil sesuai dengan tujuan dilakukannya pemeriksaan utama. Contoh di bawah ini catatan "janji 5S" untuk mendukung terlaksanya program seiso.

a) Saya tidak akan membuat barang menjadi kotor

b) Saya tidak akan menumpahkan sesuatu

c) Saya tidak akan membiarkan barang berserakan

d) Saya akan segera membersihkan barang kotor

e) Saya akan menempelkan kembali pengumuman yang terlepas

f) Saya akan menulis kembali tulisan yang telah terhapus

Pada umumnya, ada tiga langkah pembersihan yang benar. Pertama, aktivitas tingkat makro membersihkan segala sesuatu dan mencari cara untuk menangani penyebab keseluruhan yang berkaitan dengan keseluruhan gambaran. Kedua, tingkat individual, menangani tempat kerja khusus. Ketiga, tingkat mikro, di mana suku cadang dan alat khusus dibersihkan dan penyebab kotoran dicari dan diperbaiki. Ada empat langkah yang harus diikuti :

a) Bagi daerah itu menjadi beberapa bagian dan alokasikan tanggung jawab untuk tiap bagian.

b) Tentukan apa yang harus dibersihkan, urutannya, dan kemudian kerjakan. Selain itu, setiap orang harus memahami pentingnya pembersihan sehingga sumber masalahnya dapat dianalisis. 
c) Revisi cara melakukan pembersihan dan alat yang dipergunakan sehingga tempat yang sukar dibersihkan akan mudah dibersihkan.

d) Tentukan aturan yang harus ditaati supaya barang tampak seperti apa yang dikehendaki.

3) Penerapan $5 \mathrm{~S}$ secara keseluruhan belum begitu baik dilaksanakan di PT. Lakumas, maka untuk memulainya, ada langkah-langkah yang harus diperhatikan (Osada, 2002), sebagai berikut :

a) Memulai tindakan.

b) Penemuan hal baru dan keadaan yang dapat mengubah persepsi.

c) Mengubah tempat kerja dan fasilitas.

d) Mengubah manusia

4) Penelitian lanjutan perlu sampel yang lebih banyak dan bidang perusahaan yang lebih beragam agar dapat diketahui bahwa program $5 \mathrm{~S}$ merupakan salah satu fiolosofi kehidupan yang dapat diterapkan dalam banyak bidang kehidupan.

\section{Daftar Pustaka}

Mallick, Arindam. 2013. Implementation of $5 S$ in Pharmaceutical of Laboratory. International Journal Pharmaceutical Research BioScience: Punjab.

Khedkar, etc. 2012. Study of Implementing 5S Technique in Plastic Moulding. International Journal of Modern engineering Research: India.

Robbins, Stephen P. 2012. Teori Organisasi. Arcan: Jakarta.

Subkhi, Akhmad., dkk. 2013. Pengantar Teori \& Perilaku Organisasi. Prestasi Pustaka Publisher: Jakarta.

Sarwono, Jonathan. 2006. Analisis Data Penelitian Menggunakan SPSS. Andi: Yogyakarta.
Riduan. 2006. Dasar-dasar Statistik. Alfabeta: Bandung.

Sugiono,1999. Statistika Untuk Penelitian. Alfabeta: Bandung

Sudjana. 2005. Metode Statistika. Bandung: Tarsito.

Simamora, Henry. 1999. Manajemen Sumber Daya Manusia. Edisi Kedua Cetakan Kedua. Yogyakarta: STIE YKPN.

Sarwono, Jonathan. 2006. Metode Penelitian Kuantitatif dan Kualitatif. Yogyakarta: Graha Ilmu.

Riduwan. 2006. Skala Pengukuran Variabel-variabel Penelitian.

Bandung: Alfabeta.

Mustafa, Zainal. 2009. Mengurai Variabel Hingga Instrumentasi. Yogyakarta: Graha Ilmu.

Irawan, Prasetya. 2006. Penelitian Kualitatif \& Kuantitatif Untuk Ilmuilmu Sosial. Depok: Departemen Ilmu Administrasi FISIP UI.

Husein, Umar. 2005. Metode Penelitian. Jakarta: Salemba Empat.

Gunawan, Sudarmanto. 2005. Analisis Regresi Linier Ganda dengan SPSS. Yogyakarta: Graha Ilmu.

Donelly, Gibson, dan Ivancevich. 1994. Manajemen Edisi Sembilan Jilid I. Alih Bahasa Zuhad Ichyaudin. Jakarta: Erlangga.

Donelly, Gibson. 1996. Organisasi, Perilaku, Struktur, Proses. Jakarta: Erlangga.

Masaaki Imai. 1998. Genba Kaizen: Pendekatan Akal Sehat, Berbiaya Rendah Pada Manajemen. Jakarta, Pustaka Brinaman Pressindo. 


\section{BIDANG MANAJEMEN}

Masaaki Imai \& Brian Heymans.

2000. Collaborating for Change:

Gemba Kaizen. San Francisco,

Berrett-Koehler Publishers. 